\title{
PENGARUH MISALIGNMENT NILAI TUKAR TERHADAP KEBIJAKAN SAFEGUARDS DI ASEAN-5
}

\author{
Dila Vindayani \\ Dedi Budiman Hakim \\ Alla Asmara'
}

\begin{abstract}
The purposes of this study are to analyze the occurence of exchange rate misalignment and its effect on non-tariff policy in ASEAN-5. We use Panel Dynamic OLS to estimate the equilibrium real exchange rate, while for determining the opportunities of the Non-Tariff Measures (NTMs) such as safeguards measures; we use Conditional Fixed-Effects Logistic Regression. The results shows that the magnitude of exchange rate misalignment tends to be large when specific country has a domestic turmoil. In addition, undervalued currrency of exporting country will increase the chances of safeguards measures enforcement from partner countries.
\end{abstract}

Keywords:Exchange rate misalignment, non-tarif measures (NTMS), safeguards, ASEAN, ACFTA.

JEL Classification:F13, O23, 024

1 Dila Vindayani adalah Staf pada Kementerian Perdagangan dan Mahasiswa pada Program Studi Ilmu Ekonomi, Fakultas Ekonomi dan Manajemen IPB -Penulis Korespondensi (dila.vindayani@gmail.com); Dedi Budiman Hakim adalah staf pengajar pada Departemen IImu Ekonomi, Fakultas Ekonomi dan Manajemen IPB ( dedihakim@gmail.com ); dan Alla Asmara adalah staf pengajar pada Departemen IImu Ekonomi, Fakultas Ekonomi dan Manajemen IPB ( allasmara@yahoo.com ). 


\section{PENDAHULUAN}

Perdagangan merupakan salah satu bagian penting dari sektor riil yang menjadi pemicu aktivitas perekonomian. Dalam hal ini, perdagangan internasional dipercaya akan mendorong terciptanya suatu hubungan ekonomi yang saling memengaruhi antar negara serta lalu lintas barang dan jasa. Oleh karena itu, perdagangan internasional dapat dianggap sebagai fokus utama guna menghadapi era liberalisasi. Proses liberalisasi dalam perdagangan tersebut ditandai dengan mulai terbentuknya General Agreement on Tariffs and Trade (GATT) pada tahun 1947 yang perannya sekarang telah digantikan oleh World Trade Organization (WTO). Tujuan dari pembentukan organisasi ini adalah untuk meningkatkan volume dan nilai perdagangan dunia yang selanjutnya dapat meningkatkan pertumbuhan ekonomi dan kesejahteraan masyarakat di seluruh negara di dunia.

Setiap negara berupaya memperkuat posisinya di bidang perdagangan melalui keterlibatan di beragam forum bilateral, regional maupun multilateral. Negara-negara yang terlibat dalam perdagangan internasional secara teori akan mendapat keuntungan karena negara tersebut akan berspesialisasi untuk menghasilkan komoditi secara efisien. Kesepakatan negara-negara yang terjalin di kawasan Asia Tenggara melalui ASEAN, merupakan salah satu contoh kerjasama secara regional yang diantaranya membahas upaya meningkatkan perdagangan pada intramaupun extra-ASEAN. Jumlah negara anggota ASEAN saat ini mencapai sepuluh negara, yaitu Indonesia, Singapura, Malaysia, Thailand, Filipina, Brunei Darussalam, Vietnam, Laos, Kamboja, dan Myanmar dimana masing-masing negara memiliki kondisi perekonomian yang beragam dimana terdapat potensi besar untuk ditingkatkan.

\section{Tabel 1}

Total Ekspor - Impor dan Persentase Petumbuhannya di ASEAN dan Dunia, 2009-2013

\begin{tabular}{c|r|r|r|r|r|r|r|r}
\multirow{2}{*}{ Year } & \multicolumn{4}{|c|}{ ASEAN } & \multicolumn{3}{c}{ World } \\
\cline { 2 - 10 } & \multicolumn{2}{|c|}{ Export } & \multicolumn{2}{|c|}{ Import } & \multicolumn{2}{c|}{ Export } & \multicolumn{2}{c}{ Import } \\
\cline { 2 - 10 } & US\$ Juta & \multicolumn{1}{c|}{$(\%)$} & US\$ Juta & \multicolumn{1}{c|}{$(\%)$} & US\$ Juta & $(\%)$ & US\$ Juta & $(\%)$ \\
\hline \multirow{2}{*}{2009} & 813787 & - & 726951 & - & 12554000 & - & 12781000 & - \\
\hline 2010 & 1050050 & $(22,5)$ & 953113 & $(23,7)$ & 15300000 & $(17,9)$ & 15509000 & $(17,6)$ \\
\hline 2011 & 1236787 & $(15,1)$ & 1153020 & $(17,3)$ & 18327000 & $(16,5)$ & 18503000 & $(16,2)$ \\
\hline 2012 & 1252276 & $(1,27)$ & 1221838 & $(5,6)$ & 18404000 & $(0,4)$ & 18608000 & $(0,5)$ \\
\hline 2013 & 1270336 & $(1,42)$ & 1245308 & $(1,8)$ & 18784000 & $(2,0)$ & 18874000 & $(1,4)$ \\
\hline
\end{tabular}

Sumber: WTO, 2014

Tabel 1 menjelaskan total ekspor dan impor (dalam juta US Dollar) yang dilakukan oleh ASEAN dan dunia antara tahun 2009 hingga 2013 dengan menampilkan nilai pertumbuhan dari periode sebelumnya (dalam persen). Selama rentang waktu tersebut, total ekspor ASEAN terus meningkat setiap tahun, yakni dari US\$ 813.787 juta pada tahun 2009 menjadi US\$ 1.270.336 juta pada tahun 2013. Kenaikan ekspor yang cukup besar dibandingkan periode 
sebelumnya terjadi pada tahun 2010 dan 2011, yakni sekitar 22 dan 15 persen. Sedangkan ekspor pada tahun 2012 dan 2013 hanya mengalami peningkatan sekitar 1 persen. Total impor ASEAN juga mengalami kenaikan dalam lima tahun terakhir, dimana impor pada tahun 2009 yang sebesar US\$ 726.951 juta meningkat pada tahun 2013 menjadi US\$ 1.245.308 juta. Kenaikan impor ASEAN yang tinggi terjadi pada tahun 2010 dan 2011 yakni sekitar 23 dan 17 persen dari periode terdahulu. Persentase ini lebih besar dibandingkan kenaikan selama tahun 2012 dan 2013 yang hanya sekitar 1 hingga 6 persen. Secara umum, pertumbuhan perdagangan yang terjadi di ASEAN lebih cepat dibandingkan total ekspor dan impor secara keseluruhan di dunia.

Perdagangan internasional dipengaruhi juga oleh sektor moneter, yakni melalui dinamika nilai tukar mata uang. Secara teori, nilai tukar mata uang suatu negara yang terdepresiasi akan menjadikan harga domestik lebih murah dibandingkan negara lain sehingga mendorong ekspor, hal yang sebaliknya dengan apresiasi nilai tukar (Krugman et al. 2012). Namun fluktuasi dalam tingkat nilai tukar mata uang tersebut juga ditentukan rezim moneter yang berlaku dalam suatu negara.

\begin{tabular}{|c|c|c|}
\hline \multicolumn{3}{|c|}{$\begin{array}{c}\text { Tabel } 2 \\
\text { Rezim Nilai Tukar Di Negara-Negara ASEAN Periode 2012-2013 }\end{array}$} \\
\hline Negara & Periode & Rezim Nilai Tukar \\
\hline Brunei Darussalam & 2012-2013 & Currency board \\
\hline Filipina & $2012-2013$ & Floating \\
\hline \multirow[t]{2}{*}{ Indonesia } & 2012 & Floating \\
\hline & 2013 & Crawl-like arrangement \\
\hline Kamboja & 2012-2013 & Stabilized arrangement \\
\hline Laos & 2012-2013 & Stabilized arrangement \\
\hline Malaysia & 2012-2013 & Other managed arrangement \\
\hline Myanmar & $2012-2013$ & Other managed arrangement \\
\hline \multirow[t]{2}{*}{ Singapura } & 2012 & Other managed arrangement \\
\hline & 2013 & Crawl-like arrangement \\
\hline Thailand & 2012-2013 & Floating \\
\hline Vietnam & 2012-2013 & Stabilized arrangement \\
\hline
\end{tabular}

Sistem klasifikasi rezim nilai tukar dapat mengacu pada sejauh mana nilai tukar suatu mata uang ditentukan oleh pasar dan bukan oleh intervensi pemerintah (IMF, 2013). Semakin tinggi pengaruh pasar dalam penentuan nilai tukar, maka rezim akan semakin fleksibel. Mengambil contoh IMF (2013), klasifikasi rezim nilai tukar dapat dibagi menjadi empat kategori utama, yaitu: (1) hard pegs (seperti exchange arrangements with no separate legal tender dan currency board arrangements); (2) soft pegs (seperti conventional pegged arrangements, pegged exchange rates within horizontal bands, crawling pegs, stabilized arrangements, dan crawl-like arrangements); 
(3) floating regimes (seperti floating dan free floating); serta (4) a residual category (seperti other managed arrangements). Kategori hard pegs cenderung memiliki nilai tukar tetap dalam waktu lama, sehingga tingkat kepastian untuk transaksi internasional lebih tinggi. Sedangkan soft pegs cenderung menjaga nilai tukar yang stabil terhadap anchor currency dengan fluktuasi sebesar 1 hingga 30 persen tergantung dengan tingkat inflasi. Untuk floating regimes, nilai tukar secara dominan ditentukan oleh pasar dengan intervensi pemerintah yang hampir tidak ada. Rezim nilai tukar yang tidak termasuk dalam tiga kategori pertama umumnya dianggap sebagai other managed arrangements.

Mayoritas negara-negara ASEAN saat ini menganut rezim nilai tukar dalam klasifikasi soft pegs seperti yang terlihat pada tabel 2. Kamboja, Laos, dan Vietnam menganut stabilized arrangement, yang mengindikasikan fluktuasi nilai tukar sekitar 1 persen dari central rate atau memiliki margin 2 persen dalam jangka waktu minimal enam bulan. Sedangkan Indonesia dan Singapura sama-sama menetapkan crawl-like arrangement dalam rezim nilai tukarnya. Hal ini mengindikasikan nilai tukar berfluktuasi dalam tren margin minimal enam bulan dengan perubahan keseluruhan lebih besar dari 2 persen, atau dalam batas terkait proyeksi perbedaan inflasi terhadap mitra dagang utama.

Kategori lain yang juga dominan adalah floating regimes, dimana negara Filipina dan Thailand menerapkan rezim ini selama tahun 2012-2013. Tingkat nilai tukar pada rezim floating ditentukan oleh pasar dengan kondisi tidak ada lebih dari tiga intervensi selama enam bulan sebelumnya dimana masing-masing intervensi berlangsung kurang dari tiga hari kerja. Dalam periode yang sama, hanya Brunei Darussalam yang menganut kategori hard pegs yakni currency board. Rezim ini dianut ketika negara memiliki beberapa partner negara lain yang penting dalam hubungan dagang sehingga volatilitas nilai tukar mata uang yang terlalu tinggi selama waktu tertentu akan berdampak buruk. Oleh karena itu, negara tersebut dapat mematok nilai tukar mata uangnya ke weighted average dari beberapa mata uang negara partner. Malaysia dan Myanmar dikategorikan sebagai residual category dimana rezim yang dianut termasuk dalam other managed arrangement. Hal tersebut umumnya dikarenakan oleh pergeseran kebijakan yang terlalu sering selama jangka waktu tertentu akibat perubahan beberapa indikator seperti posisi neraca pembayaran dan cadangan devisa.

Rezim nilai tukar yang dianut masing-masing negara ASEAN bersifat dinamis mengikuti kondisi perekonomian terkini. Hal ini senada dengan hasil penelitian Klein dan Shambaugh (2008) bahwa peningkatan atas peluang diberlakukannya suatu rezim nilai tukar pada periode mendatang, bergantung kondisi yang terjadi dalam periode selama satu atau dua tahun sebelumnya. Penelitian Klein dan Shambaugh (2008) juga menunjukkan bahwa periode nilai tukar fixed menghasilkan kondisi bilateral exchange rate yang lebih stabil dibandingkan periode nilai tukar flexible dalam jangka pendek. Namun dalam jangka panjang, tingkat volatilitas pada periode nilai tukar fixed cenderung lebih tinggi dibandingkan periode nilai tukar flexible. 
Penetapan rezim nilai tukar selama kurun waktu tertentu dapat mempengaruhi terjadinya misalignment nilai tukar. Definisi misalignment nilai tukar tersebut yakni deviasi yang terjadi akibat adanya perbedaan antara nilai tukar riil pada kondisi aktual dengan nilai tukar riil saat ekuilibrium (Aguirre and Calderon 2005). Hasil penelitian yang dilakukan Holtemöller dan Mallick (2009) menunjukkan bahwa semakin tinggi fleksibilitas rezim nilai tukar, maka akan semakin rendah peluang terjadinya misalignment. Penelitian mereka menetapkan misalignment nilai tukar melalui terjadinya over- atau undervaluation mata uang yang dicerminkan sebagai Real Effective Exchange Rate (REER) aktual, terhadap tingkat ekuilibriumnya. Penelitian lain yang dilakukan oleh Coudert dan Couharde (2008) memperlihatkan perbedaan kondisi misalignment nilai tukar pada berbagai rezim mata uang dimana pegged currencies cenderung menyebabkan overvalued, dan floating exchange rates menyebabkan terjadinya undervalued. Sedangkan intermediate regimes berada diantaranya, dengan kecenderungan undervalued tetapi pada tingkat yang lebih rendah.

Kondisi misalignment nilai tukar berdasarkan penelitian terdahulu dapat dilihat dari dua aspek, yaitu saat terjadi overvalued currency dan undervalued currency. Dalam teori The Law of One Price (Krugman et al. 2012), kondisi overvalued currency terjadi ketika nilai tukar menyebabkan harga domestik menjadi lebih mahal dari harga di luar negeri. Sedangkan undervalued currency terjadi saat nilai tukar menyebabkan harga domestik menjadi lebih murah dari harga di luar negeri. Apabila mata uang mengalami overvalue maka dorongan impor semakin besar karena harga barang impor lebih kompetitif di pasar internasional (Naseem et al., 2009). Mata uang yang undervalue akan mendorong peningkatan produksi domestik, namun proteksi yang diterapkan di luar negeri juga turut meningkat (Irwin 2011).
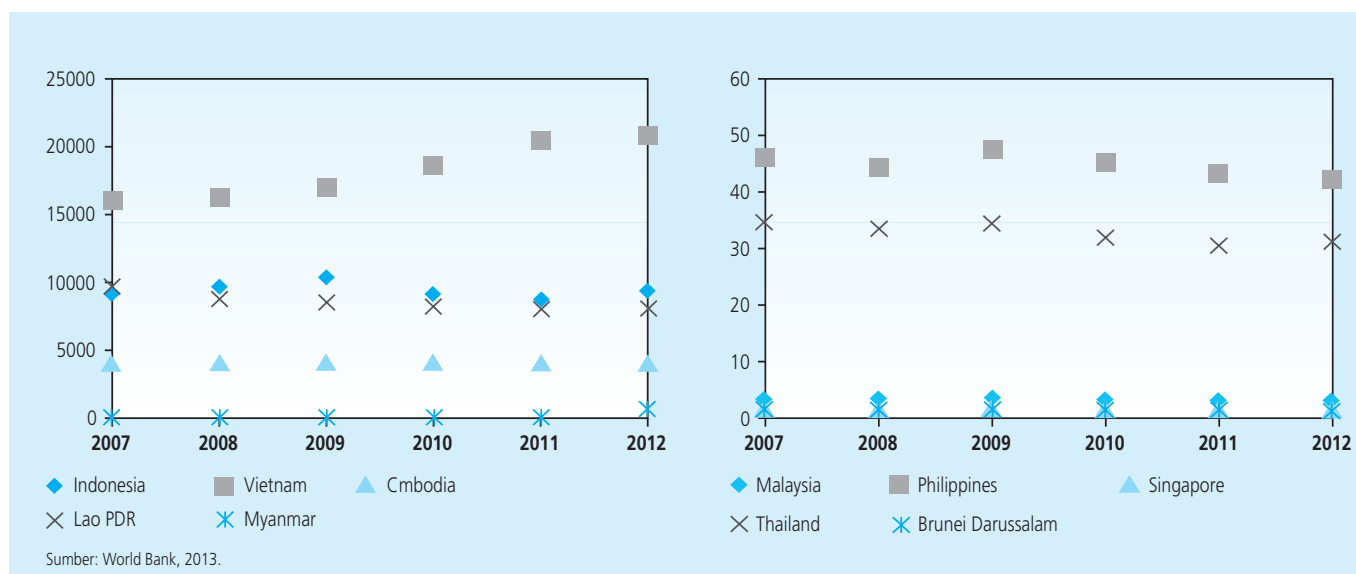

Grafik 1.

Pergerakan Nilai Tukar Nominal di ASEAN, 2007-2012 (Mata uang domestik per USD, rata-rata) 
Perbedaan dalam rezim moneter dan mata uang yang berlaku di masing-masing negara ASEAN, mengakibatkan arah pergerakan nilai tukar yang berbeda sehingga mempengaruhi perdagangan internasional. Grafik 1 menunjukkan pergerakan nilai tukar nominal dalam basis rata-rata tahunan antara periode 2007 hingga 2012 di negara-negara ASEAN dengan penghitungan mengacu pada nilai tukar rata-rata bulanan. Nilai tukar Dong Vietnam mengalami tren depresiasi selama lima tahun terakhir. Sedangkan nilai tukar Peso Philippines, Baht Thailand, dan Kip Laos cenderung mengalami apresiasi dalam periode yang sama. Untuk nilai tukar Rupiah Indonesia, pergerakan selama lima tahun cenderung berfluktuasi. Apresiasi nilai tukar dapat menyebabkan mata uang mengalami overvalued, sedangkan depresiasi nilai tukar kemungkinan akan menyebabkan mata uang mengalami undervalued. Kondisi over- atau undervalued dalam jangka waktu lama dapat mengindikasikan terjadinya misalignment nilai tukar (Holtemöller and Mallick 2009).

Efek misalignment nilai tukar terkait mata uang yang over- atau undervalue, akan mempengaruhi arah kebijakan perdagangan yang diterapkan suatu negara. Kebijakan perdagangan tersebut umumnya bersifat menghambat dimana dapat dibedakan menjadi dua macam, yaitu tarif dan non tarif. Tarif adalah pajak atau cukai yang dikenakan untuk suatu komoditi yang diperdagangkan lintas batas teritorial. Sedangkan non tarif merupakan hambatan perdagangan yang terjadi di era modern dan merupakan bentuk proteksi perdagangan yang lebih kompleks dibandingkan dengan hambatan tarif. Dalam hal ini, WTO (2012) kemudian mendefinisikan kebijakan-kebijakan perdagangan non tarif dengan istilah non tariff measures (NTM).

Laporan monitoring WTO pada Grafik 2 menunjukkan bahwa penggunaan kebijakan perdagangan restriksi berupa non-tarif di dunia telah meningkat relatif terhadap kebijakan tarif. Sejak tahun 2008, kebijakan restriksi non-tarif yang baru terus mendominasi hingga melampaui kebijakan liberalisasi tarif. Sementara itu, jumlah kebijakan liberalisasi tarif telah melebihi jumlah kebijakan restriksi tarif dalam setiap periode kecuali tahun 2009. Hal ini sejalan dengan semakin berkembangnya kerjasama regional, seperti ASEAN, yang berupaya meminimalisir hambatan demi memperlancar arus perdagangan. 


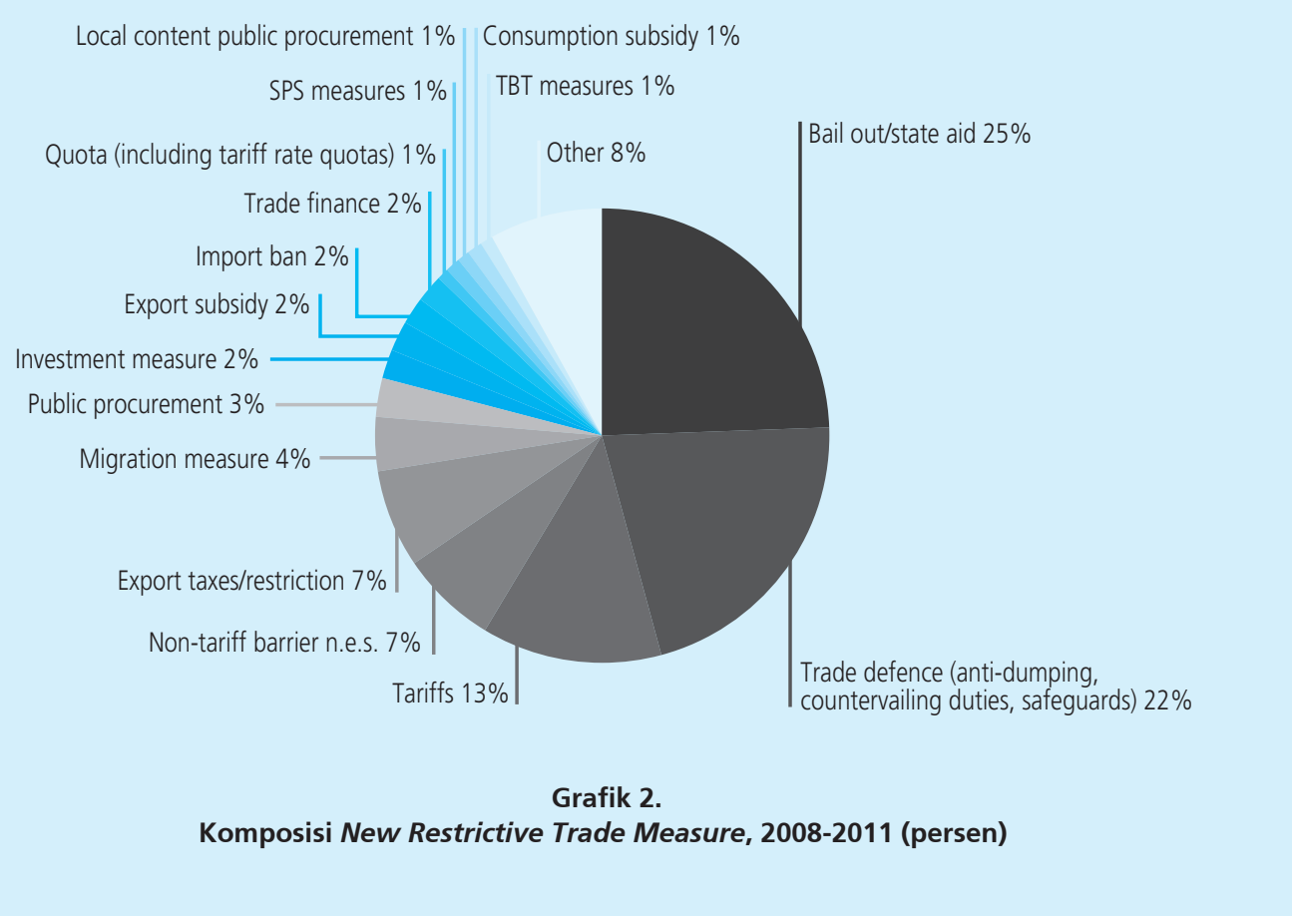

Grafik 2 menunjukkan pula bahwa kebijakan perdagangan restriksi yang paling sering digunakan yaitu bail out atau state aid sebesar 25 persen. Porsi terbesar kedua yaitu trade defence berupa anti-dumping, countervailing duties, dan safeguards, dengan total sebesar 22 persen. Sedangkan tariffs hanya menyumbang sebesar 13 persen dari seluruh hambatan. Bail out merupakan program penalangan yang dilakukan pemerintah. Trade defence merupakan tindakan yang diterapkan ketika terjadi perdagangan yang tidak adil, subsidi impor, dan lonjakan drastis dalam aliran perdagangan.

Pengaruh misalignment nilai tukar penting untuk ditelaah lebih lanjut dalam konteks perdagangan internasional. Hal ini dikarenakan dampaknya yang nyata terhadap perkembangan ekspor dan impor. Penelitian dengan menggunakan data panel di 42 negara berkembang antara tahun 1975 hingga 2004, memperlihatkan adanya dampak negatif REER misalignment terhadap ekspor (Amadou 2011). Terkait ASEAN, negara-negara yang bersepakat dalam kerjasama regional ini memiliki berbagai produk unggulan yang diperdagangkan di pasar internasional. Tingkat harga yang berlaku untuk masing-masing produk dipengaruhi oleh nilai tukar. Apabila nilai tukar menyebabkan mata uang mengalami overvalued, maka harga barang domestik menjadi lebih mahal di pasar internasional. Sedangkan nilai tukar yang menyebabkan undervalued pada mata uang akan membuat harga barang domestik lebih murah sehingga industri dalam negeri terdorong melakukan ekspor. 
Kaitan nilai tukar dengan perdagangan internasional juga menyinggung hubungan misalignment nilai tukar terhadap kebijakan perdagangan. Alasannya dikarenakan pergerakan nilai tukar secara tidak langsung akan mempengaruhi keputusan pemerintah dalam menetapkan kebijakan terkait perdagangan internasional. Matto dan Subramanian (2008) menyatakan bahwa IMF sebagai lembaga yang berwenang menangani undervalued currency akibat nilai tukar, belum berperan efektif secara mandiri. Sebaliknya, WTO dianggap lebih kredibel dan efektif dalam menyelesaikan sengketa perdagangan karena telah ada aturan tentang mata uang undervalue akibat kondisi nilai tukar, yang menjadi pelengkap diberlakukannya tarif dan subsidi ekspor. Disisi lain, penelitian Nicita (2013) menunjukkan adanya penggunaan kebijakan perdagangan untuk mengkompensasi efek nilai tukar yang dapat menyebabkan overvalued currency. Perusahaan domestik yang kehilangan daya saing akibat apresiasi nilai tukar akan melobi pemerintah untuk mengeluarkan kebijakan perdagangan yang bersifat menghambat.

\begin{tabular}{|c|c|c|c|}
\hline \multicolumn{4}{|c|}{$\begin{array}{c}\text { Tabel } 3 \\
\text { Perbandingan Jumlah Kasus NTM di ASEAN, } 2003 \text { - } 2012\end{array}$} \\
\hline & \multirow{2}{*}{ Klasifikasi } & \multicolumn{2}{|c|}{ Tahun } \\
\hline & & 2003 & 2012 \\
\hline \multirow{2}{*}{ Technical Measures } & Sanitary and Phytosanitary & 27 & 43 \\
\hline & Technical Barriers to Trade & 42 & 45 \\
\hline \multirow{3}{*}{ Non-Technical Measures } & Anti dumping & 6 & 6 \\
\hline & Safeguards & 3 & 10 \\
\hline & Quantitative Restrictions & 1 & 4 \\
\hline
\end{tabular}

Tabel 3 memperlihatkan perbandingan atas jumlah kasus NTM yang dikeluarkan oleh negara-negara ASEAN pada tahun 2003 dan 2012. Hasilnya menunjukkan bahwa secara umum kasus pengenaan NTM pada tahun 2012 lebih tinggi dibandingkan tahun 2003. Hal ini senada dengan data yang dikeluarkan World Bank pada Grafik 2 dimana persentase penerapan NTM dalam perdagangan dunia menempati porsi yang semakin besar dibandingkan tarif.

Technical measures mengacu pada sifat khusus produk seperti karakteristik, spesifikasi teknis, dan proses produksi suatu produk. Sedangkan non-technical measures mengacu pada persyaratan perdagangan, seperti syarat pengiriman, custom formalities, peraturan perdagangan, dan kebijakan perpajakan. Terkait nilai tukar, maka NTM yang akan terpengaruh dengan pergerakan mata uang berasal dari klasifikasi non-technical measures. Untuk klasifikasi tersebut, penerapan NTM yang mengalami peningkatan pesat di ASEAN adalah safeguards yakni dari 3 kasus pada tahun 2003 menjadi 10 kasus pada tahun 2012. Tindakan safeguards diterapkan akibat meningkatnya impor produk-produk tertentu sehingga mengancam kelangsungan industri domestik di negara pengimpor. Dalam hal ini, perkembangan nilai tukar dapat mempengaruhi harga produk ekspor maupun impor (Thorstensen et al. 2011). 
Berdasarkan uraian sebelumnya, terlihat bahwa hubungan antara misalignment nilai tukar terhadap perdagangan negara-negara ASEAN perlu diteliti. Hal ini selanjutnya memberikan ruang bagi peneliti untuk mengkaji lebih jauh dua permasalah berikut: pertama, bagaimana kondisi misalignment nilai tukar yang terjadi pada mata uang negara- negara ASEAN-5? Kedua, bagaimana pengaruh misalignment nilai tukar terhadap kebijakan safeguards di kawasan ASEAN-5?

Bagian selanjutnya dari paper ini mengulas teori dan literatur empiris yang terkait dengan misalignment nilai tukar. Bagian ketiga menyajikan data dan meotodologi yang digunakan dalam paper ini. Bagian keempat mengulas hasil estimasi dan analisnya, sementara kesimpulan dan saran penelitian akan diuraikan pada bagian kelima dan menjadi penutup paper ini.

\section{TEORI}

\subsection{Konsep Ekuilibrium dan Misalignment Nilai Tukar Riil}

Konsep keseimbangan pada nilai tukar riil merupakan kondisi seimbang yang terjadi apabila tidak ada kecenderungan untuk mengalami perubahan. Nilai tukar riil sebagai bagian penting dari mekanisme penyesuaian ekonomi makro, akan cenderung berubah setiap kali ekonomi terkena guncangan baru. Hal ini dapat menyebabkan perubahan nilai secara kontinyu sehingga sulit dijadikan acuan dalam menetapkan ekuilibrium nilai tukar riil. Oleh karenanya, konsep keseimbangan akan tetap mengacu pada kondisi tanpa guncangan. Disisi lain, perekonomian diasumsikan memiliki beberapa kondisi keseimbangan pada saat tertentu sehingga perbedaaan antara aktual dan ekuilibrium harus lebih nyata. Kondisi keseimbangan tersebut bergantung pada current dan expected future values yang ditetapkan atas variabel-variabel makroekonomi tertentu. Hal ini mengindikasikan bahwa keseimbangan tidak bersifat statis, namun akan berubah dari waktu ke waktu seperti perubahan yang terjadi pada nilai variabel. Oleh karenanya, keseimbangan perlu dibedakan antara short-run dan long-run equilibrium. Perbedaan antara keduanya seringkali disebut juga sebagai nilai tukar misalignment (Montiel 2002).

Contoh konkrit dapat dilihat dalam penelitian Montiel (2002) yang mengasumsikan nilai tukar riil pada setiap waktu ditentukan oleh hubungan reduced-form berikut:

$$
e=F(X 1, X 2)
$$

dimana $X 1$ merepresentasikan sustainable values of aset of real exogenous dan policy variables, sedangkan X2 merepresentasikan current values of aset of predetermined variables. Variabel terakhir merupakan variabel-variabel makroekonomi seperti upah nominal, economy's net international creditor position, dan capital stocks dalam sektor traded dan nontraded goods, yang nilainya tetap setiap saat tetapi berubah secara bertahap dari waktu ke waktu:

$$
\dot{X}_{2}=G\left(X_{1}, X_{2}\right)
$$


Dalam hal ini, nilai e pada persamaan (1) adalah nilai short-run equilibrium karena current values atas $X 2$ pada persamaan (2) akan berubah sendiri dari waktu ke waktu.

Ketika variabel-variabel makroekonomi pada $X 2$ berhenti berubah, maka kondisi tersebut dianggap telah mencapai long-run equilibrium, sehingga:

$0=G(X 1, X 2)$

dengan demikian, persamaan untuk nilai long-run atas $X 2$ menjadi:

$X 2^{*}=H(X 1)$

Kemudian disubstitusi dengan persamaan (1) menjadi:

$e^{\star}=F[X 1, H(X 1)]$

dimana $e^{*}$ adalah long-run equilibrium real exchange rate (LRER). Persamaan tersebut hanya bergantung pada sustainable values of a the exogenous dan policy variables, yang mempengaruhi e secara langsung maupun tidak langsung (melalui X2).

\section{Tindakan Safeguard}

The Agreement on Safeguards ("SG Agreement") menetapkan aturan untuk penerapan tindakan pengamanan berdasarkan Article XIX GATT1994. Tindakan safeguard didefinisikan sebagai tindakan "darurat" terkait meningkatnya impor produk-produk tertentu, dimana impor tersebut telah menyebabkan atau mengancam munculnya cedera serius bagi industri dalam negeri di negara pengimpor (Article 2). Penerapan tindakan berbentuk penangguhan konsesi atau kewajiban, yang dapat terdiri dari pembatasan impor kuantitatif atau pajak yang lebih tinggi.

Berbagai perjanjian ASEAN Free Trade Agreement (AFTA) memiliki pandangan aturan yang bersifat pro-pembangunan. Para anggota dari Australia-New Zealand Closer Economic Relations Trade Agreement (AFTA-CER), kerjasama ekonomi ASEAN-India, ASEAN-Jepang, ASEAN and The Government of The Russian Federation, dan ASEAN-Korea Free Trade Area bersepakat perbedaan tingkat pembangunan ekonomi pada negara anggota ASEAN akan dilihat dan dipertimbangkan. ASEAN-China FTA, ASEAN-Australia Australia New Zealand FTA dan ASEAN-Korea FTA memungkinkan perlakuan khusus untuk negara-negara berkembang dengan tidak menerapkan kebijakan perdagangan jika pangsa produk impor atau total impor dari negara anggota pengimpor tidak melebihi 3 persen. Hal ini serupa dengan ketentuan dalam The Agreement on Safeguards.

Indonesia menyadari adanya resiko lonjakan impor dari China paska penandatanganan kerjasama ASEAN-China (ACFTA) khususnya bagi produsen domestik produk sejenis. Bea impor lebih dari 6.000 jenis barang-barang dari China telah dibebaskan pada tanggal 1 Januari 2010 sesuai dengan kesepakatan. Ekspor seperti kelapa, karet, dan kopi mungkin meningkat 
berdasarkan kesepakatan, namun barang elektronik, baja, dan industri makanan diprediksi akan menurun.

Alasan utama dibalik kekhawatiran di atas adalah kurangnya daya saing produsen domestik, yang harus bersaing dengan barang-barang impor sejenis yang lebih murah dari China. Sebelum perjanjian mulai diberlakukan, impor dari China untuk mesin, peralatan mekanik dan listrik, serta peralatan sendiri,telah meningkat lebih dari 50 persen antara tahun 2004 dan 2008. Satu-satunya alat tersisa untuk mencegah dampak negatif yang serius bagi industri domestik dalam kasus ini adalah tindakan safeguard sesuai klausul perlindungan yang tertuang dalam kesepakatan ACFTA.

Sebagai perbandingan, Filipina telah mengambil beberapa langkah tindakan pengamanan impor dari negara-negara tertentu. Semua perselisihan yang timbul dari pelaksanaan tindakan safeguard harus dirujuk ke Dispute Settlement Unit di WTO. Selain itu, Filipina juga memiliki undang-undang nasional yang mengatur pelaksanaan tindakan pengamanan, yaitu Safeguard Measures Act (juga dikenal sebagai R.A. 8800) yang mulai berlaku pada tanggal 9 Agustus 2000. Filipina hingga saat ini telah menerapkan langkah-langkah pengamanan definitif ceramic wall and floor tiles, glass mirrors, figured and float glass, dan technical grade sodium tripolyphosphates (STPP).

\subsection{Hubungan Nilai Tukar, Output, dan Tindakan Safeguard}

Grafik 1 menunjukkan hubungan antara nilai tukar dengan output yang terkait penawaran dan permintaan. Penawaran output AS relatif terhadap output Eropa digambarkan oleh variabel $\frac{Y_{U S}}{Y_{E}}$ yang diplotkan terhadap variabel nilai tukar riil dollar US terhadap euro $q_{\$ / € \text {. Kurs }}$ riil ekuilibrium ditentukan oleh dua kurva yang berpotongan. Kurva RD menunjukkan bahwa permintaan relatif untuk produk AS secara umum terhadap produk Eropa yang meningkat saat $q_{\$ / €}$ naik karena produk AS menjadi relatif lebih murah. Dalam jangka panjang, tingkat output nasional relatif ditentukan oleh pasokan faktor dan produktivitas, dengan sedikit, jika ada, efek pada nilai tukar riil. Kurva RS menunjukkan penawaran relatif sehingga vertikal dalam jangka panjang (asumsi full-employment) dengan output rasio relatif. Dalam nilai tukar riil ekuilibrium jangka panjang, permintaan relatif sama dengan penawaran relatif. 


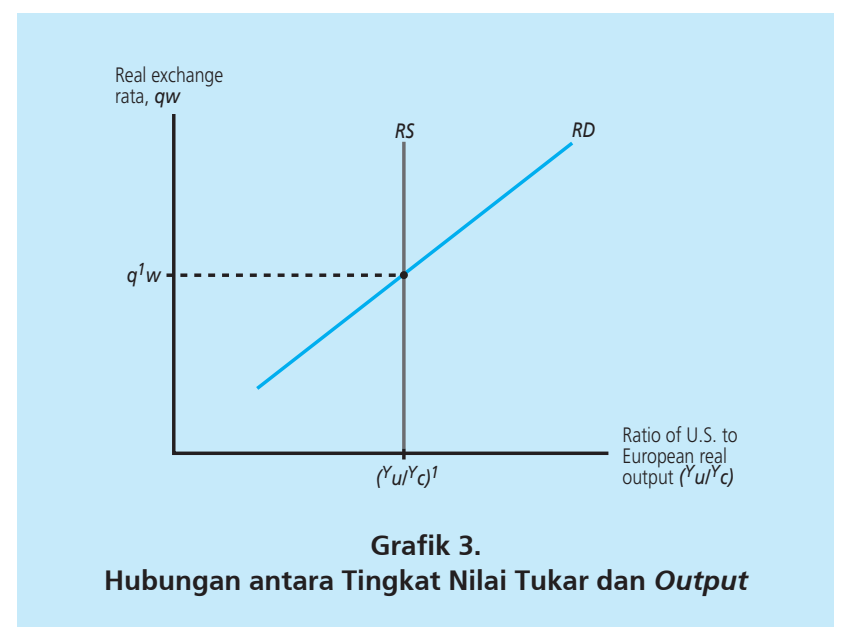

Hubungan antara nilai tukar ekuilibrium dan output yang terjadi dipengaruhi oleh berbagai faktor fundamental dalam negara. Ketika kondisi perekonomian suatu negara mengalami gejolak domestik maka output yang dihasilkan dapat menurun, sehingga kegiatan perdagangan terkena imbas penurunan. Penurunan ini berdampak pula pada penggunaan mata uang sebagai alat transaksi, dimana ketika negara terkena gejolak maka mata uang cenderung terdepresiasi. Berdasarkan situasi tersebut, pemerintah akan melakukan berbagai stimulus untuk mendongkrak industri berorientasi ekspor karena depresiasi nilai tukar membuat harga barang domestik lebih murah. Disisi lain, negara pengimpor akan melihat kondisi tersebut sebagai sinyal adanya lonjakan impor sehingga mereka akan berusaha melindungi industri domestik. Salah satu bentuk perlindungan pemerintah di negara pengimpor yaitu dengan penerapan kebijakan non-tarif berupa tindakan safeguard, terhadap mitra dagangnya.

\section{METODOLOGI}

Penelitian ini menggunakan data sekunder dari berbagai sumber. Data tersebut merupakan data panel berupa data tahunan pada periode 1994 hingga 2013 di lima negara anggota ASEAN, yaitu Indonesia, Malaysia, Filipina, Singapura, dan Thailand. Sumber data nilai tukar riil efektif berasal dari Bank for International Settlements (BIS). Data total nilai ekspor dan impor bersumber dari UN Comtrade. Sedangkan data GDP, GDP per kapita, pengeluaran pemerintah, dan konsumsi swasta diperoleh dari World Development Indicators (WDI). Sumber lain yang turut digunakan adalah World Integrated Trade Solution (WITS) guna memperoleh data pengenaan kebijakan non-tarif. 


\subsection{Model Empiris Misalignment Nilai Tukar Riil}

Penentuan misalignment nilai tukar riil dilakukan melalui tiga tahap. Pertama, real effective exchange rate (REER) diregresi terhadap faktor-faktor fundamental ekonominya. Berdasarkan penelitian Candelon et.al (2007), estimasi persamaan ekuilibrium untuk REER dengan menggunakan metode Panel DOLS adalah :

$$
\begin{gathered}
\operatorname{LN}\left(R E E R_{i t}\right)=\theta_{0}+\theta_{1} \operatorname{LN}\left(\text { OPEN }_{i t}\right)+\theta_{2} \log \left(G D P C A P_{i t}\right)+ \\
\left.\theta_{3} \log \left(G O V G D P_{i t}\right)+\theta_{4} \log \left(P_{R I G D P}\right)+v_{i t}\right)
\end{gathered}
$$

dimana, $L N\left(R E E R_{i t}\right)$ adalah log natural real effective exchange rate negara fokus i pada waktu t; $L N\left(O P E N_{i t}\right)$ adalah log natural keterbukaan negara fokus i pada waktu t; $L N\left(G D P C A P_{i t}\right)$ merupakan log natural GDP per kapita negara fokus i pada waktu t; $L N$ (GOVGDP ) adalah log natural konsumsi pemerintah per GDP negara fokus i pada waktu t; dan $L N\left(P R / G D P_{i t}\right)$ adalah log natural konsumsi swasta per GDP negara fokus i pada waktu t; sementara $v_{t}$ menunjukkan error term.

Untuk mengetahui ada atau tidaknya hubungan jangka panjang antara variabel dependen dan variabel fundamentalnya, maka sebelum estimasi dilakukanlah uji akar unit dan uji kointegrasi. Apabila variabel-variabel stationer pada tingkat yang sama dan terkointegrasi, maka estimasi persamaan REER ekuilibrium bisa dilakukan. Kedua, setelah melakukan regresi, maka persamaan dikalkulasi berdasarkan variabel fundamental dengan koefisien hasil estimasi. Hasil yang didapat nantinya merupakan REER ekuilibrium (EREER). Pada tahap ketiga, misalignment nilai tukar selanjutnya dikalkulasi menggunakan formula sebagai berikut:

$$
M I S E R_{i t}=\frac{\left(R E E R_{i t}\right)-\left(E R E E R_{i t}\right)}{\left(E R E E R_{i t}\right)} * 100
$$

dimana MISER $_{\text {it }}$ adalah persentase besarnya misalignment nilai tukar yang terjadi pada negara fokus i di waktu t. Nilai MISER it yang positif menunjukkan mata uang overvalue, sedangkan undervalue sebaliknya.

\subsection{Estimasi Model Pengaruh Misalignment terhadap Non Tariff Measures}

Dalam kaitan dengan kebijakan perdagangan, penelitian ini mengikuti estimasi yang dilakukan Jouanjean et al. (2012) untuk menangkap perubahan kebijakan perdagangan. Variabel untuk menangkap perubahan kebijakan perdagangan tersebut difokuskan kepada nontariff measures. Hipotesisnya adalah bahwa industri domestik akan melobi pemerintah untuk melakukan investigasi dan menerapkan kebijakan non-tarif, dalam rangka meminimalisir efek mata uang negara mitra yang mengalami undervalue. Dalam kasus tersebut, dapat pula diasumsikan bahwa penerapan kebijakan non-tarif akan meningkat ketika misalignment nilai tukar meningkat. 
Hubungan antara misalignment nilai tukar dengan nontariff measures berupa safeguards, diestimasi menggunakan conditional (fixed-effects) logistic regression yang merupakan salah satu bentuk model logit untuk data panel.2 Estimasi persamaannya adalah sebagai berikut:

$$
d u m_{-} s g_{i t}=\theta_{0}+\theta_{1} \text { MISER }_{i t}+\theta_{2} \operatorname{LN}(\text { TOTX })_{i t}+\alpha_{i}+\beta_{t}+\mu_{i t}
$$

dimana, dum_sg $g_{i t}$ adalah dummy tindakan safeguards yang dikenakan kepada negara fokus i pada tahun $t$, dimana nilai 1 =dikenakan safeguards dan nilai $0=$ tidak dikenakan safeguards; dan $L N(T O T X)_{i t}$ : log natural total nilai ekspor negara fokus i pada tahun $t$. Dalam persamaan tersebut, $\alpha_{t}$ dan $\beta_{t}$ merupakan seperangkat fixed effects yang mengontrol karakteristik individu dan waktu.

\section{HASIL DAN ANALISIS}

Analisis pengaruh misalignment nilai tukar terhadap kebijakan non-tarif berupa safeguards di lima negara ASEAN dimulai dengan menentukan tingkat nilai tukar mata uang pada kondisi ekuilibrium. Hal tersebut dilakukan dengan menggunakan regresi Panel DOLS terhadap variabel-variabel fundamentalnya. Selanjutnya dilakukan penentuan besaran misalignment nilai tukar yang terjadi berdasarkan perbedaan antara nilai tukar tingkat ekuilibrium dari hasil regresi dengan nilai tukar aktual yang diamati. Terakhir, pengaruh misalignment nilai tukar dan ekspor dianalisis terhadap variabel dependen berupa dummy ada atau tidak tindakan safeguard menggunakan model logit.

\subsection{Estimasi Model Persamaan Nilai Tukar Ekuilibrium}

Regresi Panel DOLS dilakukan untuk mengestimasi persamaan nilai tukar ekuilibrium. Untuk itu dilakukan beberapa langkah seperti uji akar unit dan uji kointegrasi sebelum mengestimasi persamaan nilai tukar ekuilibrium.

\section{Uji Akar Unit}

Uji akar unit dilakukan untuk mengetahui apakah masing-masing variabel stationer atau tidak. Variabel yang tidak stationer akan menghasilkan estimasi yang palsu atau regresi lancung, yakni kondisi dimana hasil estimasi menunjukan koefisien regresi yang signifikan dan nilai koefisien determinasi yang tinggi namun hubungan antara variabel independen dan variabel dependen tidak saling berhubungan. Penelitian ini menggunakan Im, Pesaran and Shin (IPS), ADF - Fisher Chi-Square, dan PP- Fisher Chi-Square.

2 Penjelasan lengkap tentang metode ini dapat dilihat pada Allison (2009) atau Hamerle dan Ronning (1995). 


\begin{tabular}{|c|c|c|c|}
\hline \multicolumn{4}{|c|}{$\begin{array}{c}\text { Tabel } 4 \\
\text { Pengujian Unit Root }\end{array}$} \\
\hline \multirow{3}{*}{ Variabel } & \multicolumn{3}{|c|}{ Nilai Statistik } \\
\hline & \multicolumn{3}{|c|}{ Level } \\
\hline & IPS & ADF-Fisher & PP-Fisher \\
\hline LNREER & -0.18339 & 8.70886 & 9.79167 \\
\hline LNOPEN & 0.12439 & 13.0648 & 14.9271 \\
\hline LNGDPCAP & 4.41792 & 0.71425 & 0.49889 \\
\hline LNGOVGDP & -0.74990 & 15.7832 & 7.05644 \\
\hline LNPRIGDP & 0.67535 & 10.2894 & 4.13860 \\
\hline \multirow{2}{*}{ Variabel } & \multicolumn{3}{|c|}{ First Difference } \\
\hline & IPS & ADF-Fisher & PP-Fisher \\
\hline LNREER & $-4.28193^{*}$ & $35.9471^{*}$ & $47.4222^{*}$ \\
\hline LNOPEN & $-7.52378^{*}$ & $63.1585^{*}$ & $69.0400^{*}$ \\
\hline LNGDPCAP & $-5.23940^{*}$ & $44.5358^{*}$ & $75.5602^{*}$ \\
\hline LNGOVGDP & $-4.48752^{*}$ & $41.7639^{*}$ & $48.7438^{*}$ \\
\hline LNPRIGDP & $-3.93902^{*}$ & $33.3112^{*}$ & $32.9623^{*}$ \\
\hline
\end{tabular}

Hipotesis nol $\left(\mathrm{H}_{0}\right)$ dari uji akar unit menyatakan variabel memiliki akar unit atau tidak stasioner. Berdasarkan tabel 5, hasil pengujian menunjukkan bahwa seluruh variabel tidak stasioner pada level. Selanjutnya, dilakukanlah pengujian akar unit pada first difference yang menunjukkan bahwa seluruh variabel telah stasioner atau menolak HO. Hal ini terlihat dari probabilitas masing-masing variabel yang lebih kecil dari taraf nyata satu persen. Setelah terbukti variabel tidak memiliki akar unit, maka langkah berikutnya adalah melakukan uji kointegrasi.

\section{Uji Kointegrasi}

Uji kointegrasi dilakukan untuk mengetahui apakah akan terjadi keseimbangan dalam jangka panjang, yakni terdapat kesamaan pergerakan dan stabilitas hubungan diantara variabelvariabel di dalam penelitian ini atau tidak. Asumsi yang digunakan yaitu $\mathrm{HO}$ menyatakan tidak ada kointegrasi sedangkan $\mathrm{H} 1$ menyatakan ada kointegrasi. Kriteria statistika untuk menolak HO yakni jika trace statistic > Critical value atau nilai $p$-value lebih kecil dari taraf nyata yang ditetapkan. 


\begin{tabular}{|c|c|c|c|c|}
\hline \multicolumn{5}{|c|}{$\begin{array}{c}\text { Tabel } 5 \\
\text { Hasil Pengujian Kointegrasi }\end{array}$} \\
\hline & & Model 1 & Model 2 & Model 3 \\
\hline \multirow{5}{*}{ Pedroni } & Panel v-Statistic & $1.467264^{* * *}$ & $1.926316^{* *}$ & $1.476314^{* \star *}$ \\
\hline & Panel PP-Statistic & $-5.137962^{*}$ & $-4.716388^{*}$ & $-4.081367^{*}$ \\
\hline & Panel ADF-Statistic & $-3.811624^{*}$ & $-3.683514^{*}$ & $-3.329542^{*}$ \\
\hline & Group PP-Statistic & $-4.340659^{*}$ & $-4.475516^{*}$ & $-3.950028^{*}$ \\
\hline & Group ADF-Statistic & $-4.398410^{*}$ & $-2.434466^{*}$ & $-3.338441^{*}$ \\
\hline Kao & ADF & $-2.746367^{*}$ & & \\
\hline
\end{tabular}

Penelitian ini menggunakan metode Pedroni dan Kao untuk melihat ada atau tidaknya kointegrasi antar variabel. Uji kointegrasi dilakukan dengan memberlakukan tiga asumsi tren yaitu No deterministic trend (Model 1), Deterministic intercept and trend (Model 2), dan No deterministic intercept or trend (Model 3). Dari hasil pengolahan, terbukti bahwa seluruh variabel terkointegrasi atau menolak $\mathrm{H}_{0}$. Hal ini mengindikasikan terdapat hubungan jangka panjang dan keseimbangan antar variabel ketika terjadi kointegrasi.

\subsection{Estimasi Kondisi Ekuilibrium Nilai Tukar Riil}

Persamaan nilai tukar riil ekuilibrium diestimasi dengan metode Panel DOLS menggunakan software EVIEWS 8. Variabel-variabel fundamental yang digunakan untuk mengestimasi nilai tukar riil ekuilibrium antara lain derajat keterbukaan suatu negara, pendapatan per kapita, konsumsi pemerintah per GDP, dan konsumsi swasta per GDP. Derajat keterbukaan suatu negara akan meningkatkan integrasi internasional sehingga meminimalisir terjadinya hambatan perdagangan. Pendapatan per kapita merupakan pendekatan yang sering digunakan untuk melihat produktivitas suatu negara. Sedangkan konsumsi pemerintah dan konsumsi swasta merupakan variabel yang digunakan untuk melihat permintaan suatu negara.

\begin{tabular}{l|c|c}
\multicolumn{3}{c}{ Tabel 6} \\
\multicolumn{1}{c}{ Variabel } & Koefisien & \\
LNOPEN & $0.217278^{* *}$ & $t$-statistic \\
\hline LNGDPCAP & $-0.425114^{* *}$ & 2.111993 \\
\hline LNGOVGDP & $0.492626^{* *}$ & -2.040452 \\
\hline LNPRIGDP & $-0.305341^{* * *}$ & 2.432294 \\
\hline R-squared & 0.964521 & -1.720296 \\
\hline
\end{tabular}


Hasil estimasi menunjukkan bahwa semua variabel fundamental memiliki pengaruh atau signifikan terhadap nilai tukar riil efektif, dimana nilai probabilitas lebih kecil daripada taraf nyata. Derajat keterbukaan berpengaruh positif terhadap nilai tukar riil efektif. Hal tersebut mengindikasikan semakin tinggi tingkat integrasi perekonomian maka nilai tukar riil akan terapresiasi karena meningkatnya penggunaan mata uang domestik untuk transaksi. Konsumsi pemerintah juga memiliki pengaruh positif terhadap nilai tukar riil efektif. Kondisi ini menunjukkan bahwa konsumsi pemerintah lebih banyak digunakan untuk belanja domestik sehingga nilai tukar riil terapresiasi. Disisi lain, pendapatan per kapita dan konsumsi swasta berpengaruh negatif terhadap nilai tukar riil efektif. Hal ini mengindikasikan adanya perubahan barang konsumsi ketika masyarakat mengalami peningkatan pendapatan, dimana barang impor lebih disukai sehingga menurunkan permintaan mata uang domestik yang menyebabkan nilai tukar terdepresiasi.

$$
\begin{aligned}
L N\left(R_{E E R_{i t}}\right)= & 0.217278 L N\left(O P E N_{i t}\right)-0.425114 L N\left(G D P C A P_{i t}\right) \\
& +0.492626 L N\left(G O V G D P_{i t}\right)-0.305341 L N\left(P R I G D P_{i t}\right) \\
& +[\mathrm{CX}=\text { INDIVID }]
\end{aligned}
$$

Model pada persamaan (9) memiliki nilai $R$-squared sebesar 0.964. Hal ini menunjukkan bahwa model estimasi nilai tukar ekuilibrium dapat dijelaskan oleh variabel derajat keterbukaan, pendapatan per kapita, konsumsi pemerintah, dan konsumsi swasta sebesar 96.4 persen. Sedangkan sisanya yakni sebesar 3.6 persen dijelaskan variabel lain diluar model. Berdasarkan koefisien yang didapat dari hasil estimasi, maka persamaan (9) dikalkulasi kembali dengan variabel-variabel fundamentalnya untuk mendapatkan nilai tukar riil ekuilibrium.

\subsection{Kondisi Misalignment Nilai Tukar di 5 Negara ASEAN}

Misalignment nilai tukar riil efektif didapat dari persentase perbedaan antara nilai tukar riil efektif yang diobservasi dengan nilai tukar riil ekuilibrium yang diestimasi. Tanda negatif dalam perhitungan menunjukkan terjadinya undervalue dimana nilai tukar riil efektif berada dibawah tingkat ekuilibrium sehingga mata uang mengalami depresiasi. Sedangkan tanda positif mengindikasikan terjadinya overvalue yakni kondisi dimana nilai tukar riil efektif berada diatas tingkat ekuilibrium sehingga mata uang mengalami apresiasi.

Mata uang rupiah mengalami overvalue jauh diatas tingkat ekuilibrium sebelum tahun 1998 karena rezim yang dianut masih menggunakan fixed exchange rate. Namun kondisi nilai tukar riil efektif tersebut berubah drastis menjadi dibawah tingkat ekuilibrium dari tahun 1998 hingga 2002. Pada gambar 7 terlihat bahwa mata uang rupiah mulai mengalami undervalue saat terjadi krisis di tahun 1998. Hal ini dikarenakan adanya ketidakstabilan politik di dalam negeri pada masa tersebut yang turut mempengaruhi perekonomian. Investasi domestik menjadi tidak menarik sehingga modal mengalir keluar negeri, dan nilai tukar rupiah mengalami depresiasi. 
Keadaan ekonomi semakin membaik pada tahun 2002 dimana mata uang rupiah mulai mengalami overvalue namun berfluktuasi dekat dengan tingkat ekuilibriumnya. Berdasarkan gambar 7, misalignment nilai tukar mata uang rupiah mengalami undervalue atau overvalue yang cukup tinggi ketika terjadi gejolak di dalam negeri.
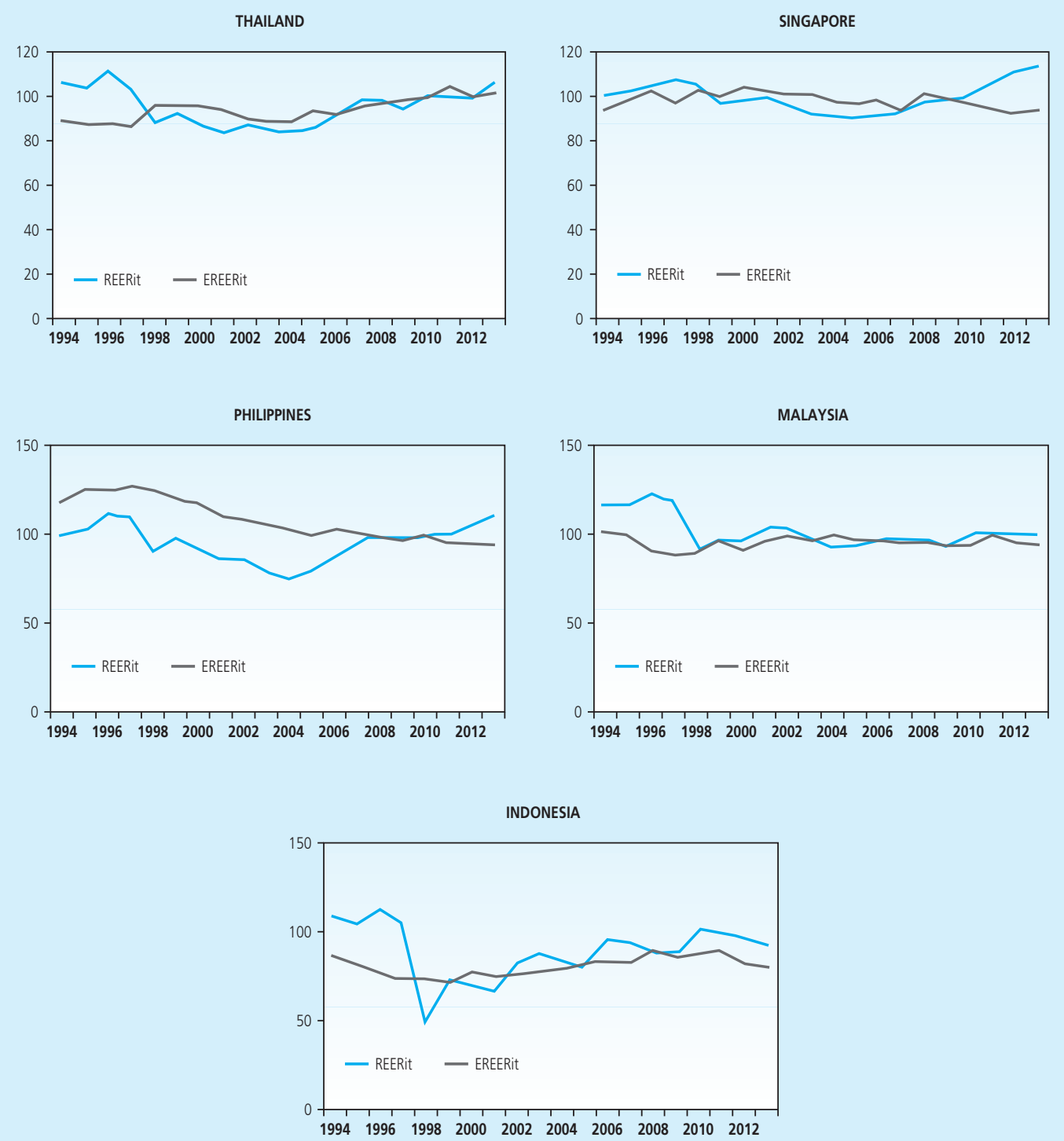

Grafik 4. 
Pada Grafik 4 terlihat bahwa mata uang ringgit terus mengalami overvalue sampai dengan pertengahan tahun 1997. Kemudian nilai tukar ringgit menjadi terdepresiasi saat terjadi krisis keuangan Asia pada Juli 1997. Namun nilai tukar ringgit saat krisis dinilai masih terlalu tinggi sehingga pemerintah Malaysia melakukan peralihan kebijakan moneter dari managed floating regimes menjadi pegged regimes pada pertengahan tahun 1998. Kebijakan tersebut dilakukan untuk meminimalisir dampak negatif dari kondisi ekonomi regional yang menurun. Dalam hal ini, pemerintah Malaysia cukup peka mempertimbangkan mata uang ringgit sebagai salah satu faktor penentu kebijakan dalam menjaga kestabilan ekonomi. Berdasarkan gambar 8, nilai tukar ringgit untuk periode selanjutnya berfluktuasi di sekitar tingkat ekuilibrium dengan persentase misalignment nilai tukar riil yang kecil.

Negara Filipina mengalami nilai tukar yang undervalue dengan persentase misalignment yang cukup besar hingga tahun 2007. Hal ini merupakan dampak diberlakukannya liberalisasi perdagangan yang dimulai tahun 1981, dan berjalan dalam tiga fase. Kebijakan tersebut disertai adanya Import

Liberalization Program (ILP) yang berusaha mengeliminasi hambatan impor (Yap 2008). Fase ketiga dimulai pada tahun 1994 dimana tarif dikenakan sebesar 3 persen untuk bahan baku dan peralatan modal yang tidak tersedia di dalam negeri. Selanjutnya, pemerintah Filipina berkomitmen untuk menyeragamkan tarif sebesar 0 hingga 5 persen untuk sebagian besar produk pada tahun 2002. Situasi ini mendorong Filipina untuk melakukan impor barang modal sehingga mata uang peso mengalami depresiasi. Pada tahun 2008, nilai tukar peso perlahan terus mengalami overvalue. Kondisi ini disebabkan terjadinya krisis keuangan global sehingga menurunkan permintaan mata uang dollar. Selain itu, aliran investasi ke dalam negeri semakin tinggi yang turut meningkatkan permintaan mata uang peso.

Tingkat nilai tukar untuk mata uang dollar Singapura terus bergerak diatas kondisi ekuilibriumnya hingga tahun 1998. Situasi ini menunjukkan perekonomian Singapura yang cenderung stabil meskipun terjadi krisis keuangan di Asia pada tahun1997. Namun pasca krisis, nilai tukar dollar Singapura mengalami undervalue sebagai dampak terjadinya penurunan ekonomi regional. Depresiasi mata uang dollar Singapura terus berlanjut hingga terjadi krisis global di tahun 2008. Berdasarkan Grafik 20, persentase misalignment nilai tukar riil di Singapura relatif kecil hingga tahun 2010. Hal tersebut dipengaruhi kebijakan moneter yang diambil pemerintah Singapura, dimana penetapan nilai tukar didasarkan pada mata uang negara mitra dagang utama. Disisi lain, nilai tukar dollar Singapura terus mengalami overvalue sejak tahun 2010. Kondisi ini dikarenakan meningkatnya aliran modal ke dalam negeri akibat adanya prospek positif di kawasan Asia, serta melemahnya nilai tukar dollar US.

Nilai tukar baht terus mengalami overvalue dengan persentase misalignment yang cukup besar hingga tahun 1996. Kondisi ini dikarenakan mata uang baht dipatok terhadap dollar US, sehingga ketika nilai tukar dollar US terapresiasi maka nilai tukar baht juga mengalami apresiasi, begitu pula sebaliknya. Hal tersebut menarik banyak investor asing untuk menanamkan 
modalnya di Thailand. Mata uang baht yang terapresiasi menjadikan Thailand kurang kompetitif dalam melakukan ekspor. Selain itu, tingkat nilai tukar baht juga dirasa terlalu tinggi. Akibatnya investor mulai menjual mata uang baht pada tahun 1997 sehingga nilai tukar mengalami undervalue. Keadaan perekonomian Thailand kembali stabil sejak tahun 2006, dimana nilai tukar baht berfluktuasi di sekitar kondisi ekuilibriumnya dengan persentase misalignment yang rendah.

\subsection{Analisis Model Pengenaan Tindakan Safeguards}

Semakin terintegrasinya pasar ASEAN meminimalisir pengenaan hambatan tarif akibat adanya kesepakatan kerjasama antar negara. Disisi lain, mata uang negara-negara di ASEAN belum terintegrasi sehingga tingkat nilai tukar mata uang ditentukan pula dengan kondisi perekonomian dalam negeri. Oleh karena itu, untuk mendorong perekonomian domestik dengan semakin terintegrasinya pasar, maka diterapkan hambatan non-tarif. Terkait hal ini, penelitian hanya menyertakan tindakan safeguards sebagai variabel dependen yang mencerminkan hambatan non-tarif. Variabel safeguards tersebut merupakan variabel dummy yang bernilai 1 atau 0 . Metode yang digunakan untuk menganalisis pengaruh misalignment nilai tukar terhadap safeguards adalah Conditional Fixed-Effects Logistic Regression dengan menggunakan software STATA 11. Variabel independen lain yang digunakan dalam analisis adalah total nilai ekspor.

\begin{tabular}{|c|c|c|c|c|c|}
\hline \multicolumn{6}{|c|}{$\begin{array}{c}\text { Tabel } 7 \\
\text { Hasil Estimasi Faktor yang Mempengaruhi Pengenaan Safeguards }\end{array}$} \\
\hline Variabel & Koefisien & SE & Probabilitas & OR & $(95 \% \mathrm{Cl})$ \\
\hline$\theta_{1}$ MISER $_{i t}$ & -0.0189411 & 0.0112149 & 0.091 & 0.9812371 & $(0.96,1.00)$ \\
\hline$\theta_{2} L N(T O T X)_{i t}$ & 0.11406 & 0.0222261 & 0.000 & 1.120819 & $(1.07,1.17)$ \\
\hline
\end{tabular}

Tabel 7 merupakan hasil estimasi model logit dengan dummy safeguards sebagai variabel dependennya. Variabel - variabel independen memiliki pengaruh yang signifikan terhadap variabel dependen. Nilai probabilitas lebih kecil dari taraf nyata satu persen untuk variabel total nilai ekspor dan sepuluh persen untuk variabel misalignment nilai tukar. Estimasi koefisien yang negatif menunjukkan bahwa misalignment nilai tukar positif (mata uang mengalami overvalue) pada negara fokus i akan menurunkan peluang dikenakannya tindakan safeguards terhadap negara tersebut. Nilai odds ratio menunjukkan peluang yang mungkin terjadi dimana penghitungannya berasal dari koefisien yang dieksponensialkan. Berdasarkan hal tersebut, terjadinya misalignment nilai tukar yang overvalue sebesar satu persen akan meningkatkan peluang dikenakan safeguards sebesar 0.98 kali lipat dari kondisi awal. Sedangkan bila misalignment nilai tukar mengalami undervalue dengan besaran yang sama yakni satu persen, maka peluang dikenakannya safeguards $=0.98 \wedge(-1)=1.019121621$ atau meningkat sebesar 
1.02 kali dari kondisi sebelumnya. Dengan demikian, resiko pengenaan tindakan safeguards lebih rentan terjadi saat mata uang mengalami depresiasi.

Total nilai ekspor memiliki estimasi koefisien yang positif mengindikasikan bahwa peningkatan ekspor yang dilakukan negara fokus i akan meningkatkan peluang dikenakannya tindakan safeguards ke negara tersebut. Peningkatan total nilai ekspor sebesar satu persen yang dilakukan negara fokus i akan meningkatkan peluang dikenakannya tindakan safeguards sebesar 1.12 persen.

\section{KESIMPULAN}

Hasil penelitian ini menyimpulkan bahwa persentase misalignment nilai tukar yang terjadi di 5 negara ASEAN, baik saat mata uang overvalue maupun undervalue; umumnya cukup besar ketika disebabkan oleh gejolak perekonomian di dalam negeri. Situasi seperti krisis global di tahun 2008 tidak berpengaruh besar terhadap fluktuasi nilai tukar riil efektif di sekitar tingkat ekuilibriumnya. Selain itu, penelitian juga menemukan bahwa peluang negara pengekspor mendapat tindakan safeguards dari negara mitra, akan lebih besar ketika tingkat nilai tukar riil negara pengekspor mengalami undervalue dimana hal tersebut menyebabkan mata uang terdepresiasi.

Misalignment nilai tukar yang terjadi di negara-negara ASEAN umumnya telah diminimalisir oleh pemerintah di masing-masing negara melalui penyesuaian arah kebijakan moneter dengan kondisi terkini. Untuk lebih mempercepat dampak negatif yang mungkin dirasakan, maka sebaiknya negara-negara ASEAN bekerjasama dalam penerapan kebijakan moneter. Terkait tindakan safeguards yang diberlakukan negara-negara ASEAN, hal ini mungkin dapat diminimalisir apabila terdapat kestabilan nilai tukar. Contohnya adalah Singapura yang melakukan pembobotan nilai tukar dengan beberapa negara mitra dagangnya sehingga mata uang bergerak disekitar ekuilibrium. Dengan demikian, integrasi ekonomi terutama ASEAN Economic Community (AEC) diharapkan dapat berjalan baik.

Penerapan kebijakan non-tarif untuk melindungi perekonomian domestik, diprediksi akan semakin meningkat seiring meningkatnya kerjasama perdagangan internasional. Dalam penelitian ini, kebijakan non-tarif yang dibahas hanya tindakan safeguards karena adanya keterbatasan data. Oleh karena itu, diperlukan kajian yang lebih mendalam mengenai berbagai kebijakan non-tarif lain seperti subsidi, SPS, dan TBT. 


\section{DAFTAR PUSTAKA}

Aaditya M, Arvind S. 2008. Currency undervaluation and sovereign wealth funds: a new role for the world trade organization. The World Bank Policy Research Working Paper. WP4668.

Alessandro N. 2013. Exchange rates, international trade and trade policies. UNCTAD. Study series no. 56.

Alvaro A, Cesar C. 2005. Real exchange rate misalignments and economic performance. Central Bank of Chile Working Papers. No. 315.

Bertrand C, Clemens K, Katharina R, Tom VV. 2007. Long-run exchange rate determinants: evidence from eight new EU member states, 1993-2003. Elsevier Journal of Comparative Economics. 35 (2007): 87-107.

[BIS] Bank for International Settlements. 2014. Real Effective Exchange Rates Data. http://www. bis.org/statistics/eer/. [terhubung berkala].

Diallo IA. 2011. The effects of real exchange rate misalignment and real exchange volatility on exports. MPRA Paper.No. 32387.

Douglas I. 2011. Trade policy and exchange rates. IMF/World Bank/WTO Workshop on International Trade. The World Bank, 2 December 2011.

[IMF] International Monetary Fund. October 2013. Annual Report on Exchange Arrangements and Exchange Restrictions 2013.

Hamerle, A., and G. Ronning. 1995. Panel analysis for qualitative variables. In Handbook of Statistical Modeling forthe Social and Behavioral Sciences, ed. G. Arminger, C. C. Clogg, and M. E. Sobel, 401-451. New York: Plenum.

Josef TY. 2008. Policy Coherence Initiative on Growth, Investment and Employment: The Case of the Philippines (Policy Coherence and Critical Development Constraints in the Philippines). Paper prepared for the International Labour Organization (ILO).

Maria-Agnes J, Jean-Christophe M, Ben S. 2012. Reputation matters: spillover effects in the enforcement of US SPS measures. The World Bank:Policy Research Working Paper Series. WPS5935.

Michael WK, Jay CS. 2008. The dynamics of exchange rate regimes: fixes, floats, and flips. Elsevier Journal of International Economics. 75 (2008) 70-92.

N.A.M Naseem, Hui-Boon T, M.S Hamizah. 2008. Exchange rate misalignment, volatility and import flows in Malaysia. MPRA Paper.No. 41571.

Oliver H, Sushanta M. 2009. Does the choice of a currency regime explain real exchange rate misalignment?.The AIEFS session at ASSA Annual meeting 3-5 January, 2009. 
Paul Allison, 2009, Fixed Effects Regression Models, Series: Quantitative Applications in the Social Sciences, SAGE Publication.

Paul RK, Maurice O, Marc JM. 2012. International Economics : Theory \& Policy. Boston (US): Pearson.

Peter JM. 2002. The long-run equilibrium real exchange rate: theory and measurement. Macroeconomic Management: Programs and Policies. Washington DC (US): IMF.

[UN COMTRADE] United Nations Comtrade. 2014. http://comtrade.un.org/data/. [terhubung berkalal.

Vera T, Emerson M, Lucas F. 2011. Exchange rate misalignments and international trade policy: impacts on tariffs. Policy Dialogue: Redefining the Role of the Government in Tomorrow's International Tradeat UNCTAD XIII Pre-Conference Event 26 - 27 March 2012.

[WB]World Bank. 2014. Official Exchange Rate (LCU per US\$, period average) Data. http://data. worldbank.org/indicator/PA.NUS.FCRF. [terhubung berkala].

[WDI] World Development Indicators. 2014.http://data.worldbank.org/indicator. [terhubung berkalal.

[WITS] World Integrated Trade Solution. 2014. Non-tariff Measures Data. http://wits.worldbank. org/. [terhubung berkala].

[WTO] World Trade Report. 2012. An Inventory of Non-Tariff Measures and Services Measures.

[WTO] World Trade Organization. 2014. Total Merchandise Trade Data. http://stat.wto.org/ StatisticalProgram/WSDBViewData.aspx?Language=E. [terhubung berkala].

[WTO] World Trade Organization. 2014. Non-Tariff Measures Data. http://i-tip.wto.org/goods/ Forms/TableView.aspx. [terhubung berkala]. 
84 Buletin Ekonomi Moneter dan Perbankan, Volume 18, Nomor 1, Juli 2015

Halaman ini sengaja dikosongkan 